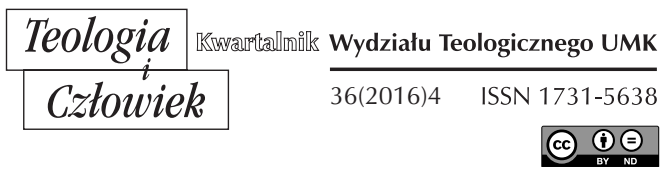

KS. KAZIMIERZ SKOCZYLAS*

TORUŃ-WŁOCŁAWEK

\title{
SPRAWOZDANIE Z KONGRESU PEDAGOGÓW RELIGII 1 KATECHETYKÓW OBSZARU NIEMIECKIEGO
}

DOI: http://dx.doi.org/10.12775/TiCz.2016.052

Kongres odbywał się w dniach 8-11 września 2016 roku w Niemczech. Jako miejsce obrad wybrano dom rekolekcyjnym św. Pawła w Leitershofen koło Augsburga. Kongres otworzyła po południu 8 września 2016 przewodnicząca stowarzyszenia pedagogów religii i katechetyki (Arbeitsgemeinschaft katholische Religionspadagogik/Katechetik) prof. Claudia Gärtner z Uniwersytetuu w Dortmundzie. Przewodnicząca wyjaśniła dlaczego przyjęto tytuł kongresu „Randezvous mit der Realität. Religionspädagogische Umgang mit herausfordernden Zeichen der Zeit”. Słowo Randezvous niesie ze sobą konieczność poznania drugiej osoby. Takiego poznania drugiego człowieka potrzeba dziś w pedagogice religii, bowiem w niemieckiej rzeczywistości niemal na każdym kroku spotyka się ludzi o różnych postawach wobec religii. Potem Przewodnicząca przedstawiła program tego kongresu.

* Ks. Kazimierz Skoczylas jest adiunktem w Zakładzie Teologii Praktycznej w Wydziale Teologicznym UMK (kskoczylas@diecezja.wloclawska.pl). 
W drugiej części wprowadzenia do tematyki kongresu wystąpiło kilku prelegentów, aby rzucić snop światła na problemy, które ujawniają się w rzeczywistości. Pierwsza zabrała głos prof. Andrea Lehner-Hartman z Wiednia, która podkreśliła największe wyzwania dużego miasta. Następny prelegent zwrócił uwagę na kształcenie zawodowe i jego możliwość budowania głębszej tożsamości zawodowej. Kolejny pedagog prof. Reinhold Boschki pokreślił potrzebę dialogu z Żydami. Religia przywołuje wspomnienia i one rzutują na teraźniejszość i przyszłość. Zwrócono uwagę na spojrzenie na rzeczywistość z perspektywy polskiej i chorwackiej. Uwypuklono potrzebę spojrzenia międzyreligijnego.

Następnego dnia do południa wygłoszono trzy referaty. Pierwszy przedstawiła profesor Regina Polak z Uniwersytetu Wiedeńskiego. Mówiła ona o fenomenie migracji i wyzwaniach w obliczu zmieniającej się rzeczywistości w Europie. Migracja była udziałem wielu w Europie po II wojnie światowej. Szacuje się, że w tym okresie było tu około 60 milionów migrantów. Kontynuując podkreśliła, że we współczesności możliwe są migracje o wymiarze światowym. Niosą one ze sobą konflikt pokoleń, polaryzację w społeczeństwie a w relacji do religii różne przejawy antysemityzmu, rasistowskiej nienawiści wobec muzułmanów, salafizm, młodzieżowy dżihad oraz ateizm i utratę wiarę, zróżnicowanie Kościołów i chrześcijaństwa. Także obecna migracja do Niemiec rodzi niepokój, że wszystko się zmieni i to wywołuje niepokój i agresję. Wyzwaniem staje się pojęcie zła, winy i rozumienie Boga. Przybycie chrześcijan z różnych szerokości geograficznych niesie ze sobą radykalne spostrzeganie spraw religijnych, zróżnicowane pojęcie zła i przesuwanie moralnych granic ludzkiego postępowania $\mathrm{W}$ przyszłości fenomen migracji będzie oznaczał przejście od społeczeństwa monokulturowego do wielokulturowego.

Następnie wystąpił prof. Rudolf Englert z Uniwersytetu DuisburgEssen. Mówił on trudnościach światopoglądowych i fundamentalizmie. Narastające tendencje fundamentalistyczne przyczyniają się do zmniejszenia się do krytycznego spojrzenia na rzeczywistość. Mamy do czynienia ze zmniejszaniem się grup intelektualistów z zakresu filozofii i teologii. Natomiast rośnie liczba osób, które posiadają wiedzę rozumianą jako zbiór informacji. Tymczasem pojawia się deficyt rozeznania, które łączy się z religijnym spojrzeniem na rzeczywistość. Jednocześnie religijne wyjaśnienia nie są dla współczesnych przekonujące, bo w religijne wyja- 
śnienia nie zawsze są przekonujące dla współczesnego człowieka. Mimo to trzeba stawiać podstawowe religijne pytania. W nich nie chodzi przede wszystkim o to, aby przekazać wiedzę religijną, ale także prowadzić do pogłębienia religijnego rozeznania.

Kolejnym prelegentem był prof. Bernd Schröder z uniwersytetu w Getyndze. Podjął on zagadnienie bezwyznaniowości i pluralizmu religijnego. Przedstawił je z perspektywy protestanckiej. Podkreślił, że w Niemczech wśród wyznań religijnych dominują katolicy i protestanci. Są też małe wspólnoty wolnych Kościołów oraz ci, którzy nie należą do żadnego wyznania. Spośród osób bezwyznaniowych $80 \%$ nie poszukuje żadnej religii. Jego zdaniem pluralizm konfesji i religii wymaga jak najszybszego kształcenia religijnego, które oparte będzie na współdziałaniu różnych religii. W niemieckiej pedagogice religii rozwinęły się różne modele międzyreligijnego kształcenia. Są to modele wspólnego poszukiwania wartości religijnych przez chrześcijan z Żydami i muzułmanami. Jest też propozycja otwarcia się na role małych wspólnot religijnych takich jak świadkowie Jehowy, scjentologowie, zachodni buddyzm i inne. Profesor podkreślił, że wewnątrz wspólnot religijnych dostrzega się przejawy pluralizmu. Na to rzutuje fakt, że w Niemczech na 80 mln ludności 15,9 miliona obywateli Niemiec ma korzenie migracyjne. To niesie ze sobą rezonans $\mathrm{w}$ postaci pluralizmu. Jednocześnie zauważa się, że centrum chrześcijaństwa przemieściło się z Europy do Ameryki i Afryki. Zarazem w książkach do nauki religii brak jest wiedzy na temat życia chrześcijan w krajach poza Europą. Kolejnym problemem w Niemczech są osoby nienależące do żadnej konfesji (konfesionslose). Według profesora ta kategoria osób obejmuje około 26 mln osób z czego 80\% żyje w Niemczech wschodnich a 20\% w Niemczech Zachodnich. Wiąże się to z pewnym modelem życiowym. W Niemczech zachodnich bycie religijnym należy do kultury religijnej człowieka natomiast na wschodzie Niemiec przejawem tej kultury jest bycie osobą bez wyznania. W ramach grupy bezwyznaniowej da się wyróżnić cztery typy postaw: bezwyznaniowy wierzący, których szacuje się około $11 \%$, bezwyznaniowi tolerancyjni (17\%), normalni bezwyznaniowi (21\%), oraz ateiści (51\%). Konsekwencją rosnącej liczby osób bezwyznaniowych jest też spadająca liczba ochrzczonych. W 2015 roku w Niemczech na 738 tys. urodzonych w rodzinach chrześcijańskich blisko 200 tysięcy nie zostało ochrzczonych. Kolejną rzeczą są wystąpienia młodych z Kościoła 
z powodów społecznych. Jedną z przyczyn narastającego problemu bezwyznaniowości jest brak wsparcia religijnego $\mathrm{w}$ rodzinie. Mimo tych postaw podejmowany jest dialog z osobami bezwyznaniowymi. Podejmuje się go nie po to, aby ich pozyskać do wyznania, ale przede wszystkim po to, aby umocnić w nich chęć samorozwoju, kształtowania siebie.

Po południu zajęcia odbywały się zajęcia $\mathrm{w}$ trzech grupach tematycznych. Wspólny cel tych zajęć objęto tytułem „Przykładowe rozwiązania i dyskusje na temat wyzwań religijno-pedagogicznych". Pierwszy blok, którego moderatorem była prof. Claudia Gärtner podjął problematykę heterogeniczności środowiska i środowisk życia. Wprowadzeniem do dyskusji było wystąpienie profesora Hansa Joachima Sander z uniwersytetu w Salzburgu oraz profesora Bernharda Grümme z uniwersytetu w Bochum. Pierwszy akcentował, że współczesne środowisko sprawia, że żyjący w nim człowiek czuje się bezsilny. Doświadcza tej bezsilności gdy spotyka silniejszego od siebie. Poczucie bezsilności niesie ze sobą bezradność. Ale bezradność oznacza zarazem specyficzną siłę. Bezradność przynosi upokorzenie a z niego mogą powstać różne przejawy odwagi. Trzeba też dodać, że bezradność rodzi brak pewności siebie. W takiej sytuacji pojawiają się resentymenty. Cecha charakterystyczną obecnych czasów jest to, że coraz więcej ludzi żyje w mieście. W sytuacji globalizacji oznacza to coraz większą migrację. Migranci szukają rozpoznania ich godności. Jednocześnie migranci wyzwalają też resentymenty w społeczeństwie. Ci zagrożeni przez nie chcą okazać siłę tam gdzie inni mają swoje słabości. Jeśli nie chcemy popaść $\mathrm{w}$ resentymenty, to trzeba, aby chrześcijanie podjęli na nowo dziedzictwo Rzymu. Przejawem tego dziedzictwa, zdaniem prof. Sander jest z jednej strony stałe dążenie do doskonałością z drugiej stale musi ono zwalczać barbarzyńców.

Prof. Bernhard Grümme skupi się na doświadczeniu „innego”. Podtytuł jego wystąpienia „Między ślepotą środowiska a dopasowaniem się do środowiska". Lekcja religii jest miejscem skupienia się na człowieku. Uczeń przynosi ze sobą wiele problemów, które musza być rozwiązane. Nie można pozostać na propozycjach pomocy w wykluczenia, ale trzeba na gruncie pedagogiki religijnej odnieść się do teologicznego obrazu człowieka. Po tym uczestnicy tego bloku odnosili się do podjętych w wystąpieniu kwestii. W drugiej części tego bloku tematycznego podjęto zagadnienie wykluczenia. Wprowadzeniem były referaty dr Annebelle Pithan 
z Comenius Institut Münster oraz prof. Miriam Schambeck z uniwersytetu we Freiburgu. Po wysłuchaniu referatów odbyła się dyskusja w grupie.

Drugiemu blokowi przewodniczył prof. Wolfgang Weirer. W pierwszej części podjęto problematykę nowych fundamentalizmów i odporności na nowe spojrzenie na rzeczywistość a w drugiej części problemy międzyreligijności i oczekiwania na poznanie prawdy. Wprowadzeniem do tego był bardzo ciekawy referat prof. Georga Langerhorsta z Augsburga o dialogu międzyreligijnym. Autor skupił się przede wszystkim na dialogu między trzema wielkimi religiami monoteistycznymi czyli między judaizmem, islamem a chrześcijaństwem. Prof. Langenhorst od dawna interesuje się problematyką ekumeniczną. Jednak rzeczywistość niemiecka zmusiła go do zainteresowania się możliwościami interreligijnego uczenia się na lekcji religii. Pierwsi naukowcy, którzy interesowali się tym zagadnieniem byli zachwyceni możliwościami dialogu. Szybko jednak się rozczarowali dialogiem międzyreligijnym. Najczęściej dialog międzyreligijny jest rozumiany jako relacja między chrześcijanami a Żydami i islamem. Szybko zmieniająca się niemiecka rzeczywistość zmusza do podejmowania tej problematyki. Nie wiemy czy ten „inny” z którym chcemy rozmawiać tego chce. Stopniowo w Niemczech, podkreślał prelegent, rozwija się teologia porównawcza. Jest ona nazywana Trialogiem. Łączy się z prowadzeniem debaty przez trzy strony. Nie oznacza to, że w tym dialogu zamiast dwóch występują trzy strony. To podkreśla treściową stronę tego dialogu. Ta treść nie jest możliwa tylko do ujęcia w innych pojęciach, które będą miały podobne znaczenie. W niej można jednak dość precyzyjnie określić wymianę i zbliżenie w komunikacji pomiędzy tymi trzema wielkimi religiami. Co byłoby więc trialogicznym myśleniem i działaniem? O to pytał prof. Langenhorst. Odpowiadając podkreślał, że z bojaźni przed Bogiem, z szacunku przed innymi religijnymi tradycjami, z szacunku przed inaczej wierzącymi ludźmi, ze świadomości pluralizmu obok nas egzystujących ludzi chodzi o coraz lepsze wzajemne poznanie, które pozwala coraz lepiej kroczyć swoją drogą. Wspólną bazą dla tej teologii jest najpierw to, że religie te mają semickie pochodzenie oraz Boga rozumieją jako łaskawą i pełną miłości miłosiernej osobę. One podzielają też wiarę, ze osobowy Bóg objawił się w historii, przede wszystkim w historii Izraela. Wszystkie one też opowiadają o stworzeniu świata przez Boga. One opowiadają też o grzechu pierworodnym, które przedstawia biblijna historia Adama 
i Ewy. Łączy je też postać Noego. Odwołując się do obrazu Noego opowiadają historię potopu jako reakcję na ludzkie złe zachowania a zarazem treść niosącą nadzieje zachowania świata od zniszczenia. W niej Abraham i Mojżesz są przedstawiane jako dwa typy proroków, którzy stoją przed Bogiem, aby przekazać ludziom wolę bożą. Przykazania i Prawa zawarte w pismach świętych są traktowane jako wskazania, które mają umożliwić udane życie przed Bogiem i ludzi między sobą. Te trzy religie zgadzają się też w przekonaniu, że z relacji z Bogiem da się wyprowadzić podstawowy etos, który pozwala uregulować prywatne, społeczne i polityczne kontakty dla dobra społeczności. W niej akcentuje się też, że w Jezusie i Maryi, jako ludziach pochodzących z narodu izraelskiego, Boże wskazania są szczególnie widoczne. One też znają nadzieję, że Bóg na końcu czasów doprowadzi świat do pełni i każdy człowiek ma w nim nadzieję na życie wieczne. Ta teologia pozwala poznać innych. Ona rozwija postawę pragnienia poznania prawdy o innej religii. Dla jej rozwoju konieczne jest zderzenie się z innymi religiami. Wiele uwagi skupia na sobie Abraham jako figura pierwszej monoteistycznej wiary. Abraham bowiem jest ważną postacią dla judaizmu, chrześcijaństwa i islamu.

Ta teologia ma pewne konsekwencje dla pedagogiki religii. Najpierw trzeba przyjąć dydaktyczną zasadę, że w refleksji i planowaniu treści i dróg nauczania zamiast obok powinno być szczególnie ważne wspólne przemyślenia z judaizmem, chrześcijaństwem i islamem. Jednak nie w każdej jednostce dydaktycznej ta perspektywa dla uczniów powinna być widoczna ale dobrze dozowana i dokładnie przemyślana. Następnie podkreśla się zasadniczy wymiar wewnątrz religijno-pedagogicznego dyskursu. W kontekście pluralizmu pedagogiki religijnej nie da się ograniczyć do małego zakresu chrześcijańskiego doświadczenia. Trialogiczne otwarcie umożliwi rozszerzenie spojrzenia na inne religie i na nie religijne ujęcia. Konieczne jest też umożliwienie spotkań i konkretną wymianę ekspertów, rozmowę między równymi sobie specjalistami a także współpracę i wspólne inicjatywy oraz projekty, które pogłębią wzajemne zrozumienie. Będzie to możliwe przez współpracę $\mathrm{w}$ grupach przedmiotowych. W wielu szkołach rzeczywistością jest wspólne zakończenie religijnych i etycznych umiejętności. Wspólnie dadzą się religijne i etyczne wymiary lepiej wykorzystać w codziennym życiu szkoły. Przez wspólne wystąpienia umocnią monoteistyczne religie ich obecność i możliwości wpływu w sfe- 
rze publicznej. Trialog poprzez fazy wspólnego uczenia i różne wymiany nauczycielskiej może umożliwić wspólne działanie przez dwóch uczących przedstawicieli różnych religii na lekcji religii czy też w trakcie kilku faz jakiejś lekcji. Bezpośrednio w nauczaniu metoda projektów mogą grupy różnych wyznań i religii ze sobą współpracować.

Wypowiedzi prof. Langerhorsta naświetlali z perspektywy austriackiej od strony katolickiej prof. Martin Jäggle z Wiednia oraz prof. Zekirija Sejedini z uniwersytetu w Innsbrucku z perspektywy islamskiej.

Trzeci blok dotyczył zagadnienia: Bezwyznaniowość - Alternatywne dydaktyki dla lekcji religii. Moderatorem tego bloku był Guido Hunze. Jako wprowadznie do tej problematyki były dwa przedłożenia. Pierwsze przedstawił prof. Jan Woppowa z uniwersytetu Padeborn, a drugie Jochan Bauer z Landesinstitut fur Lehrerbildung Hamburg W drugiej części dyskutowano zagadnienie „Bezwyznaniowość: Alternatywne formy organizacyjne dla lekcji religii - perspektywa międzynarodowa”. Wprowadzeniem były wystąpienia dr Dominika Helblinga z Luzerny oraz dr Peter Schreiner z Comenius Institut w Münster. Potem przewidziano dyskusję nad wystąpieniem.

W kolejnym dniu przewidziano pracę w grupa metodą workshops. Przewidziano pięć propozycji grup tematzcynzch. Pierwszy workshop pod przewodnictwem prof. Manfreda Rieggera nosił tytuł „Pedagogika religijna i ucieczka. Wyzwania dla religijnej formacji uwydatnione przez odniesienie się do Ojcze nasz w grupach uciekinierów. Drugi workshops prowadzony przez prof. Markusa Tomberga z Fuldy skupił się na katechezie do Pierwszej Komunii. Trzeci dotyczył międzyreligijności i poszukiwania prawdy w innej religii. Jemu przewodniczył prof. Martin Jäggle z Wiednia. Czwarty podjął problematykę międzyreligijnych spotkań. Ostatni dotyczył zadań przedmiotu religia służących rozwojowi kompetencji ucznia jako odpowiedź na religijny pluralizm w Szwajcarii.

Dla piszącego najbardziej interesujący wydawał się pierwszy workshop podejmujący problematykę ucieczki w pedagogice religii. Prowadzący go prof. Manfred Riegger z uniwersytetu monachijskiego odwołał się do doświadczeń bawarskich. Uciekinierzy przebywający w tym kraju uczestniczą w kursach języka niemieckiego. W trakcie nauki ujawniają się ich różne doświadczenia. Wśród nich jako szczególnie silne dochodzą do głosu ich postawy religijne. Wśród migrantów uczestniczących w tych 
kursach są tam też chrześcijanie z różnych regionów świata i różnych wyzwań a także muzułmanie różniący się bardzo swoimi tradycjami. Trzeba zdać sobie sprawę, że ci ludzie niemal wszystko stracili, ale zachowali swoją religie. Spostrzega się, że jest ona dla nich szczególnie cenna. Ona daje im punkt oparcia w nowym kraju. Stąd nauczyciele języka niemieckiego potrzebują religijnych kompetencji, aby odnosić się z szacunkiem do ich postaw religijnych. W Bawarii w procesie edukacji tworzy się klasy przejściowe. Trafia do nich młodzież ze słabymi zdolnościami językowymi. Po rozwinięciu potrzebnych kompetencji językowych trafiają oni do klas normalnych. Doskonalenie umiejętności językowych trwa około roku. Wielki wzrost tych klas przejściowych zanotowano w roku 2014/2015. Gdy w pierwszym semestrze było ich 309 to w drugim semestrze było ich już 580 . W tych klasach istnieje silna potrzeba lekcji religii. Podjęcie na lekcji religii prowadzonej w języku niemieckim umożliwi im szerszy kontakt z kulturą kraju do którego przybyli a także pomoże lepiej się wzajemnie rozumieć. Prof. wraz zespołem opracował program dla klasach przejściowych pozwalający mówić do chrześcijan pochodzących $\mathrm{z}$ bardzo różnych stron świata (od Europy po Afrykę) o Ojcze nasz. Jego propozycja ma także charakter terapeutyczny. Ma ona pomóc uwolnić się od przeżywania traumy związanej z dotychczasowym życiem. Wraz z zespołem prof. Riegger przygotował pomoc dydaktyczną „Unterwegs mit dem Vaterunser. Mit flüchtlingen und Einheimischen das Gebet sprechen und verstehen lehrnen“. Jego propozycja wychodzi naprzeciw oczekiwaniom wielu tamtejszych nauczycieli religii, którzy muszą te problemy na bieżąco przeżywać i rozwiązywać. Sytuacja wielu migrantów chrześcijańskich o różnych tradycjach religijnych wymaga wysokich kompetencji od nauczycieli religii. Ta pomoc ma ułatwić im poruszanie się $\mathrm{w}$ tej problematyce.

Po południu przewidziano punkt programu, który miał wskazać dokąd zmierza niemiecka pedagogika religii oraz po niej sesję posterową. Problemy pedagogiki religii rozważano w trzech grupach. Pierwsza skupiła się na jej umiędzynarodowieniu, druga na rozwoju nowych adeptów pedagogiki a trzecia na publikacjach $\mathrm{z}$ zakresu pedagogiki religii. $\mathrm{W}$ trzeciej grupie $\mathrm{w}$ problematykę publikacji wprowadził prof. Kropac z Eichstät. Podkreślił, że dziś możliwości publikacji z tego zakresu oferują nastepujace czasopisma „Rellis”, czasopismo diecezjalne „Eulenfisch”, „Kateche- 
tisch Blätter, Religionspädagoische Beitrege. Zauważa się też możliwość publikacji w Internecie np WiRelex. Pojawia się też digitalizacja dawno opublikowanych artykułów. W publikacjach ważna jest też liczba punktów. Tu problemem jest czasopismo „Katechetische Blätter”, które nie ma punktów a stanowi ważne forum wymiany myśli katechetycznej.

Sesja posterowa zaś była okazją dla rozpoczynających karierę naukową do zaprezentowania swoich badań. Uczestnicy przedstawiali swoje propozycje badań lub osiągnięte rezultaty. Wzięło w niej udział kilkanaście osób.

$\mathrm{W}$ ostatnim dniu $\mathrm{w}$ programie przewidziano wypowiedz teologa islamskiego, jak on widzi katolicką lekcję religii z perspektywy islamskiej. Swoje stanowisko przedstawił prof. Zekrija Sejednini z uniwersytetu w Innsbrucku. Całość zakończyło podsumowanie wyniku obrad. Przedstawiono też wybrany w trakcie kongresu nowy zarząd stowarzyszenia. 